\title{
The Detection of Corruption and The Role of Accountant in Achieving Good Public Governance
}

\author{
Rozmita Dewi YR \\ rozmita.dyr@upi.edu \\ Universitas Pendidikan Indonesia
}

\begin{abstract}
The Government of Indonesia has been conducting various corruption eradication efforts; however, these have not been able to effectively prevent corruption in Indonesia. Indonesian Corruption Eradication Commission (KPK) has managed to unravel corruption cases through a thorough detection and investigation. Therefore, this study aims to find out the process of KPK in detecting corruption cases. This study also aims to find out the role of accountant related to the detection of corruption cases in the efforts to create good public governance. This study uses qualitative method. The informants in this study consists of five practitioners and academics who are competent in detecting and investigating corruption. The study shows that the detection of corruption is conducted through the process of gathering evidence. Based on UU KUHP the five evidences are witness testimony, expert testimony, documentary evidence, hints evidence and suspect/defendant testimony. Having obtained a minimum of two evidences, the case can go further from the inquiry stage to the investigation stage. KPK regularly conducts assessment on the various probabilities of corruptions in government organizations at both state and regional levels as well as in other state institutions. Based on the result of the identification of potential corruption and reports from the public KPK detects corruption by using a searching technique of perpetrator network and objects of corruption as well as using follow the money technique to calculate the losses of state. The study also shows that accountant have a role in the detection of corruption in the investigative audit process as well as in calculating losses of state resulted by corruption. The embodiment of good public governance by government accountants, government auditors and accountant's educators is conducted through the realization of fraud awareness and risk detection as well as the investigation of corruption. This study have implication for the public in describing the effective process of corruption identification in Indonesia. This study is also expected to encourage regulators in determining the effective detection of corruption cases in Indonesia.
\end{abstract}

Keyword : Detection, Corruption, Accountant and Good Public Governance.

\section{THE BACKGROUND}

The thrive of corruption cases in Indonesia has given the impression that the process of corruption prevention in Indonesia has not been effectively applied. The government has made many prevention efforts ranging from the enactment of anti-corruption laws to the establishment of state institutions whose function is to carry out the prevention, detection and investigation of corruption cases. According to the National Strategy on the Prevention and Combating of Corruption Long Term (2012-2025) and the Medium Term (2012-2014), various prevention efforts actually been carried out, among others, by improving the quality of licensing services, as exemplified some areas through the establishment of one-stop service (service one roof). However, in implementation, public perception still reflects a weakness, particularly regarding licensing regulations in the area that leaves so many loopholes for corruption. Similarly, the increase in service tax, there are still unresolved problems with a single and integrated program identification number identification number (singular). In addition to tax issues, the completion and integration of the program is believed to be a lot of work-related home eradicating corruption. Another thing that has a lot of homework is associated with the procurement of goods and services that are often considered to be the realm of the wet for the occurrence of corrupt practices. Various breakthrough efforts should be made to minimize corruption spaces in these areas [1]. Based on the data from the Supreme Court decisions over twelve years from 2011 to 2012, the amount of state losses due to corruptions reaches Rp 168, 19 trillion. Besides, based on the findings of the Supreme Audit Agency in IHPS 2010-2014, five provinces the highest amount of the loss is Riau, Papua, North Sumatra, Southeast Sulawesi, and West Papua. In addition, the amount of total loss of the year 20102014 from the accumulation of 34 (thirty-four) provinces found Audit Board is Rp. 10,812,198,368,369.70 from 58.153 cases. The amount is significant enough to cause harm to the public due to the allocation of state funding that should have been used for the financing and development of the country was misused by corruptors to enrich and benefit themselves and their group. On one side the proven of corruption cases indicate the low awareness of anti-corruption culture; on the other side, however, this indicate the seriousness of government investigators for corruptions in conducting the detection and investigation of corruptions.

The previous study shown that corruptions occur not only in the developing countries but also in the developed ones [2]. Corruptions also occur in Germany regarding confidential contributions for re-election campaigns [3]. This proves that corruptions can even happen to a country with a good democratic system as well as a country with a strong anti- 
corruption system. The corruption cases in Indonesia is different with those in other countries. Corruption cases in the world in general involve three interrelated partiesbureaucrats, politicians and businessmen. The involvement of this three is based on a correlation that politicians generally require funds in the electoral process and funding is generally carried out by entrepreneurs who have economic interests in it. As a return of favor politicians will make some rules for bureaucrats in order to allocate state budget for economic interests of the businessmen who desires procurement projects of government goods and services [4]. While the corruption cases in Indonesia involves not only the three, but also the fourth-the judiciary.

Despite the fact that corruptions occur in many countries and with different patterns. Very few people know how they can be revealed, whose get involved in them, how the corruptors do that. Therefore, it is highly needed a study that describe the effective process of corruption detection. A party considered to have the ability to detect the occurrence of corruption is the accountant. Therefore the role of accountants in the detection of corruption is extremely needed. Some worldwide organizations whose focus is achieving good public governance, such as Transparency International, USAID and World Bank, emphasize the role of accountant in the fight against corruptions [5].

Accountant has an important role to create an environment of accountable and transparent financial reporting. The three parties (bureaucrats, politicians and businessmen) involvement in the act of corruption can be minimized through the role of the accountant by Firstly; Auditing campaign fund that is considered to be a form of most common corruptions related to contribution in the effort to win the election of a candidate. The contribution from businessmen for some people is a part of political investments to gain a bigger benefit from the victory of the candidate. Secondly; auditing the procurement of goods and services that is considered to be a form of most common corruptions. The involvement of bureaucrats, politicians and businessmen in the act of corruption of the procurement of goods and services can be minimized through the audit of the accountant so that the procurement procedure will be more accountable and transparent. Thirdly; reporting the accounting of the company through a good governance mechanism. So that the expenses of the businessmen can be identified well [6].

There are not many studies that associate the role of accountant in reducing corruptions as well as achieving good public governance. This research is the development of the study conducted by Neu et al (2012) and uses a qualitative approach to describe the relationship between corruption and accountant. The main discrepancy with the previous one is the development of the study on the detection of corruption cases in Indonesia which are different with those committed in other countries.

Based on the description above, this study aims first to identify the techniques of corruption detection in Indonesia. Second to find out the role of accountant in reducing corruptions as well as achieving good public governance. The results of this study shows that KPK collects the corruption evidences in various ways. To obtain sufficient preliminary evidence, KPK must have a minimum of two sufficient evidences to escalate the case from the inquiry process to the investigation process. KPK regularly studies the possibility of corruptions in the government institutions so that KPK may provide certain inputs to the relevant institutions for prevention efforts to do. After identifying the risks of corruption, KPK will evaluate the corruption case informed by the public. The identification of corruption is conducted by using a searching technique of perpetrator network and objects of corruption as well as using follow the money technique to calculate the losses of state. The study also shows that accountant have a role in the detection of corruption in the investigative audit process as well as in calculating losses of state resulted by corruption. The embodiment of good public governance by government accountants, government auditors and accountant's educators is conducted through the realization of fraud awareness and risk detection as well as the investigation of corruption.

This study contributes, Firstly to give an understanding regarding the efforts of the corruption detection and describe the role of accountant in minimizing the corruption cases. Secondly this study may encourage the government to optimize the role of accountant in reducing corruptions and to make regulations regarding the minimum competences and qualifications of investigators in order to tun an effective corruption detection technique in Indonesia.

\section{LITERATURE REVIEW}

\section{A. Corruption}

There are various definitions of corruption in the history of Indonesia. Corruption includes bribery, fraud, manipulation, blackmail, gratification and nepotism. Corruption is generally defined as the misuse of public office for personal gain. This includes, for example, the illegal sale of state assets by the officials, kickbacks in the procurement of public sector, bribery, and theft of government funds.

Corruption is a significant financial crime which is estimated by the World Economic Forum to cost about 5 per cent of global GDP or \$2.6 trillion dollars. Explanations of corruption, like explanations of crime, tend to focus on the individuals who commit corruption and the wider conditions which give rise to corrupt behaviour. Approaches designed to reduce corruption usually propose stiffer sanctions, institutional reforms and the passing of new laws [7]. Corruption which has been a character since the new order regime until the current government becomes an obstacle in achieving good governance [8]. Corruption is a result of patronage practice (a patron-client relationship). She says that corruption in Indonesia is not the characteristic of local culture, but is the result of history and economic development. The main cause lies in the history of patronage politics. While the other causes are budgeting problems, low salaries, lack of anticorruption strategy and lack of transparency in the legal system as well as social barriers as the secondary cause [9].

Historically, colonialism in Indonesia has created a wellestablished indigenous society that collect economics rewards based on the transfer of foreign parties rather than the structure of the market. This rent seeking class became the source of unofficial tax and later known as the emergence of corruption. This is due to the emergence of overlapping government 
functions that this class eventually became an institution that perform accountability on itself [10].

\section{B. Framework}

One of cheating forms that has become the government's main concern is the thrive of corruption. Corruption is generally defined as the misuse of public office for personal gain. This includes, for example, the illegal sale of state assets by the officials, kickbacks in the procurement of public sector, bribery, and theft of government funds. The government has made various efforts to reduce corruption. One of them is the enactment of Law No. 31 Year 1999 which recognizes the death sentence for the corruptors, even though this Law has never been used to resolve corruption in Indonesia [11].

There are three ways that may reduce corruption, i.e. prevention, detection and investigation. Prevention is the best way because this effort is considered to be more efficient than after corruption cost out the country. Detection is another effort to do by paying attention to the symptoms of corruption. If they show significance, so it is a "red flag" that indicates a huge possibility of corruption that it needs an investigation to find out the perpetrator, the motive, the method and the amount of state losses that comes up from the corruption itself [12].

The detection of corruption is important in Indonesia because of the poor bureaucratic system there. The symptoms of fraud, including corruption, consist of 1) irregularities in the accounting process; 2) weaknesses in internal control; 3) anomalies in the transaction or occurrence; 4) profligacy and excessive lifestyle; 5) unusual behaviors and 6) tips and complaints. These six symptoms will help the investigators decide whether there will be an act of corruption or even show that in fact there has been a corruption [13].

Karyono (2013) explains that corruption itself consists of 1) conflict of interest; this occurs when the bureaucrats as the government manager have their own interests. For example, the provision of goods and services by the companies of the bureaucrats or the companies designated by the bureaucrats; 2) bribery is a gift or a solicitation or an acceptance of valuable things to influence the actions of a person because of his job. Bribery consists of kickbacks and compensation for the auction (bid rigging); 3) illegal gravities is giving something valuable to someone because his decisions may provide benefits to the giver; and 4) economic extortion is a payment requested by the bureaucrats to the partners for the undertaken decision so that the partners may have benefit from it.

The accounting and control systems of an organization within the government can be observed to detect the symptoms of corruption. The study conducted by Xun $\mathrm{Wu}$ shows that a better accounting is considered to be able to reduce corruption. Accountants have a role in corruption reduction. Another study conducted by them shows that the assessment of internal control and monitoring are considered to be able to reduce corruption [14]. Therefore, the government auditors always conduct an analysis of internal control adequacy within an organization as their first step.

An adequate internal control is still considered to raise the possibility of corruption if there is a collusion among divisions. This requires further action, i.e. investigation, from the government auditors to find out the motives, the perpetrators and the methods of corruption as well as the state losses resulted from it. The process of investigation to prove corruption can be conducted in many ways. Audit investigation, taxation investigation and follow-the-money investigation can be used to prove corruption [15].

Various techniques of investigation may be used simultaneously by the government investigators or auditors to suit the conditions and situations. In some cases the main perpetrator can be easily identified. On the other hand many cases involve a bigger network that it needs more techniques of investigation. Here is the framework of this study:

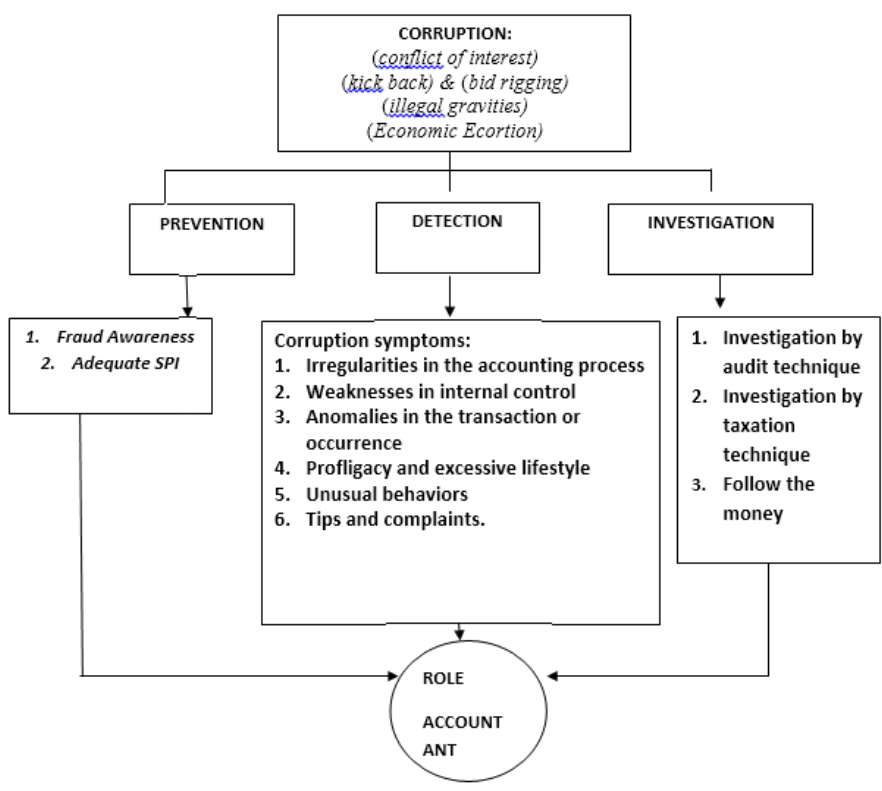

Fig. 1. Framework

\section{RESEARCH METHOD}

In this study, the research object is the detection of corruption. This study was conducted with a qualitative approach. The data used for this study are primary data. The choice of the informants in this study uses non-probability sampling. The sampling technique used was purposive sampling.

Once the informant is chosen, the appropriate techniques of collecting data is determined in order to obtain data that corresponds to the purpose of research and to meet the standards of expected data. Individuals who become informants in this study consists of government accounting experts, forensic accounting experts and public accountants. Here is the table of informants.

The table 1 shows the list of informants for this study. The informant who becomes the object of research is the government auditor experienced in KPK, lecturer and researcher in the field of forensic accounting, and public accountant experienced in auditing financial statements.

The techniques of collecting data are interviews and documentation. In this study, analysis of the data is Analysis of Field Data of Miles and Huberman Model. Activities in qualitative data analysis are conducted interactively and takes place continuously until completed, until data saturation [16]. The activities in data analysis include data reduction, data 
displays, and conclusion drawing/verification. In the technique of data validation, the writer uses triangulation technique with theory.

TABLE I. LIST OF INTERVIEWEES OR INFORMANTS

\begin{tabular}{|l|l|l|}
\hline $\begin{array}{c}\text { No } \\
\text { Interviewee/Informant }\end{array}$ & \multicolumn{1}{|c|}{ Background } & \multicolumn{1}{|c|}{ Reason of Choice } \\
\hline Interviewee/Informant 1 & Government Auditor & Experienced in KPK \\
\hline Interviewee/Informant 2 & $\begin{array}{l}\text { Lecturer and } \\
\text { researcher in the field } \\
\text { of Forensic } \\
\text { Accounting }\end{array}$ & $\begin{array}{l}\text { Experienced in } \\
\text { conducting research in } \\
\text { the field of fraud and } \\
\text { forensic accounting }\end{array}$ \\
\hline Interviewee/Informant 3 & $\begin{array}{l}\text { Lecturer and } \\
\text { researcher in the field } \\
\text { of Forensic } \\
\text { Accounting }\end{array}$ & $\begin{array}{l}\text { Experienced in } \\
\text { conducting research in } \\
\text { the field of forensic } \\
\text { accounting }\end{array}$ \\
\hline Interviewee/Informant 4 & Public Accountant & $\begin{array}{l}\text { Experienced in } \\
\text { performing audits of } \\
\text { financial statements }\end{array}$ \\
\hline
\end{tabular}

a. Source: Data Processing

\section{FINDINGS AND DISCUSSIONS}

\section{A. The Technique of Corruption Detection in Indonesia}

Prevention, detection and investigation are the efforts to reduce corruption. Prevention is conducted to anticipate the occurrence of corruption. It is considered to be the most ideal way to reduce corruption because the cost to spend will be much smaller than after corruption cost out the country. The other way is the detection of corruption. It is conducted to find out the possibility of corruption. It is started with collecting evidence from the symptoms of corruption that lead to it. While the investigation is conducted to find out the perpetrators of corruption, the scenario of the perpetrators involvement and the amount of state losses resulted from the corruption. The detection becomes important to learn because collecting an adequate preliminary evidence to investigate the involvement of certain individual or group in the act of corruption is considered to be the first gate in revealing corruption completely. Based on the in-depth interview with the participants, it can be concluded that there is no special pattern to structurally describe the best technique to use, because each of corruption cases is unique and has a certain characteristic that the technique of corruption detection is different for each case. This is due to the crime scene, the perpetrators and the network within, and the type of corruption. However, the technique of detection in revealing corruption is generally started with describing the collected evidences and assessing the risk of corruption.

\section{1) The Types of Collected Evidences}

In the process of inquiry, investigation and prosecution, the evidence has an important role to expose corruption. The investigation must find at least two sufficient evidence. Based on UU KUHP the investigators may use five evidences, i.e. witness testimony, expert testimony, documentary evidence, hints evidence and suspect/defendant testimony.

To collect and evaluate evidence is the hard part that will be faced by the investigators in exposing corruption. Corruption is an extraordinary crime so that the process of collecting evidence is different with other crimes. For example,
KPK investigators have the right to wiretap conversations among parties allegedly involved in corruption. The confidential nature of corruption makes it necessary to have a technique of collecting evidence. Although this may lead to potential misuse of evidence for specific purposes by the investigators themselves.

Based on the in-depth interview with the participants, it is found out that the evidences collected by KPK investigators consists of various types, i.e. interviews, financial statements, physical calculations, recorded conversations, witness testimony, reperformance by the investigators, goods or money of bribery, supporting documents and other evidence. Each evidence certainly have a different degree of competence. One evidence may provide a higher confidence than other evidence. For example, witness testimony has a lower degree of competence than goods of bribery. Therefore, after collecting the evidences, the investigators analyze each of them by taking into account the degree of competence of each of them.

There are differences in the length of time in the process of collecting evidence. The lack of sufficient evidences makes lots of corruption cases unable to reveal in the trial. In fact in many cases the investigators experience difficulties in collecting evidence because lots of parties indeed obstruct the process. This obstruction may be in form of a pressure from the closest party to the suspect, such as his family member, his boss in his company or even the security guard who is actually hired to protect him. Evidences collected by the auditors are different in quality so that the evidence with a higher degree of competence may provide a sufficient conviction to conclude the result of the audit [17]. According to them each evidence takes a different length of time that implicates to the resources to spend by different auditors.

\section{2) Analysis of Potential Corruption}

Corruption Eradication Commission (KPK) functions to prevent and detect corruption. So that KPK regularly analyses the potential corruption that may cost the state. Fraud risk assessment is also carried out in general audit (audit of financial statements). Fraud risk assessment in an audit is conducted by identifying area that is at risk of fraud, analyzing and communicating this to the audit team in order to allow the change of audit procedure based on the risk of the fraud [18]. Areas with high potential of fraud may lead the auditors expand audit coverage and vice versa.

Based on the interview with the participants, it is found out that KPK conducts a study on potential corruption at national interest areas as follows: 1) health and education; 2) mineral, coal and energy security; 3) infrastructure and 4) state revenue. This study is conducted by LITBANG KPK (the research and development division of KPK). This study is conducted by analyzing the aspects of operations, regulations, governance and others. In analyzing those aspects KPK will assess the potential loss resulted from corruption by conducting a process called corruption impact assessment in which there will be three aspects to measure, i.e. adequacy, availability and openness.

After in-depth study, KPK will communicate the findings to the relevant leader within the institution regarding the possibility of potential state loss resulted by corruption, and then KPK will ask the management to conduct an improvement as suggested by KPK. This shows that KPK 
carries out the function of prevention, and is not only focused on detection and investigation. KPK's role of prevention is considered to be more effective in reducing corruption than conduction and investigation, because this won't spend as much cost as after the corruption occurred.

The allegedly weakening efforts against KPK by certain parties, referring to several cases that eventually dragged the leaders of KPK to the trial, has become a concern of all related to the commitment of state in reducing corruption. Whereas KPK, the Police and the Attorney General, which are the incharge organizations of handling corruption, should synergize to realize a free-from-corruption state administration. The government must strengthen the role of KPK because it has a function to prevent corruption that the other in-charge institutions don't. It is necessary to regularly identify and assess the potential corruption to ensure the state administration is free from corruption. KPK conducts studies on the potential corruption within different span of time, from six months to one year. After conducting studies and discussing with the management of the institution, KPK then monitors the institution within different span of time in realizing the recommendations from KPK.

3) The Detection of Corruption in Indonesia

Detection is conducted to assess the risk of corruption through an in-depth study by LITBANG division. The symptoms of fraud in general irregularities in the accounting process, weaknesses in internal control, anomalies in the transaction or occurrence, profligacy and excessive lifestyle, unusual behaviors, tips and complaints [19]. Therefore, based on the interview with the participants, it is found that the detection is not only based on the analysis of LITBANG, but also based on public complaints. However, the percentage of complaints and public participation in providing information regarding corruption is relatively small.

By conducting corruption risk assessment, KPK will be able to measure the commitment of an institution in improving the management that if the result of monitoring and evaluation shows that the recommendations is not properly implemented, KPK may order arrestment. And this will identify the perpetrators for entering the stage of corruption trial. The investigators use various techniques to reveal corruption, such as corruption network analysis, follow the money and taxation. Theodorus (2011) states that the detection and investigation may be conducted with various techniques, such as audit, taxation and follow the money. Based on the interview with the participants those techniques can be understood as follows:

\section{a) Corruption Network Analysis;}

This technique is conducted by developing a perpetrator of corruption and linking him to the other perpetrator. As described in the previous section, corruption cannot be committed by a sole perpetrator. Because of this unique nature, the involvement of other parties needs to be examined more deeply. In analyzing the perpetrators, the investigators conduct the corruption network analysis both horizontally and vertically. Horizontally they trace a possible perpetrator from a horizontal relationship, such as co-workers, relatives or horizontal family members. While vertically they trace a possible perpetrator from a vertical relationship, such as bosses, subordinates, and vertical family member like children, mother and father.
Corruption is considered to be an extraordinary crime. Because of this, it needs an extraordinary handling as well. Therefore, the detection process may lead to the investigation. So to ensure the involvement of other parties, besides the main suspect, KPK will ask another team of KPK to conduct field observation to find other possible suspects. The involvement of other parties may provide a comprehensive picture of the object of corruption as well as potential state loss resulted by corruption.

\section{b) Taxation Analysis;}

The technique of taxation analysis or so called net worth method is also conducted to seek the risk of illegal income. It is conducted by seeking taxable income that has not been reported by the taxpayer. Based on the interview with the participants, it is found that the taxpayer in Indonesia according to tax regulations is obliged to count, calculate, pay and report his taxation statement. This analysis is conducted by looking at net worth in the beginning of the year that can be seen from the reduction of the asset with the liabilities. Then the analysis also calculates net worth in the second year so that the difference of unreported net worth can be found out. The same method may be used to seek any illegal income based on the calculation of the net worth. Therefore, public officials are required to regularly report their assets in order to analyze their net worth before and after serving in certain position. If their net worth significantly increases without any accountable evidence, it may indicate an act of corruption.

\section{c) Follow the Money Analysis;}

In general, the act of corruption is always associated with money laundering laws. In any act of crimes, the perpetrator generally tries to remove any trace of his involvement. The same goes to corruption. The perpetrator of corruption tends to keep himself away from the evidence by committing money laundering. However, the money of corruption can be revealed by tracing the flow of money. This technique is called follow the money. Based on the interview with the participants, the investigators generally will trace the source of wealth of the suspects. This technique is a relatively simple, but it will face the challenge of numerous data. Thus the investigators usually see the patterns of the cash flow. The perpetrator usually involves his family members or his relatives to keep and preserve the assets of corruption, so that the trace of assets is also conducted against his family members and his relatives. PPATK has a role to provide information regarding the cash flow of the suspect or defendant to trace the deployment of assets of corruption.

That in case the defendant is unable to prove his disproportionate wealth to his income or source of wealth enhancer, then his testimony may strengthen the evidence of his involvement. This is called Reversal Burden of Proof that is limited and balanced. The defendant has the right to prove that he does not commit any act of corruption, and the attorney general needs to prove his charges [20].

\section{B. The Role of Accountants in Reducing Corruption}

Accountant has a role in the efforts of corruption reduction. Besides the role of corruption prevention through the development of anti-corruption culture, accountant also has a big contribution in the detection of corruption. With the accounting and audit capability, a new science called forensic accounting has been developed. That it involves three 
scientific fields: accounting, audit and legal. Accountants is a profession of this forensic accounting.

\section{1) The Role of Accountants in Calculating State Loss}

From any act of corruption, the state suffers a certain amount of loss. Accountants usually have a big role in calculating state loss precisely. Based on the interview with the participants, it is found that KPK investigators involve forensic accounting that is usually used by BPK and BPK as well as a division of KPK that is capable in calculating state loss. State loss is calculated based on the amount of state lost assets resulted by corruption. The calculation is conducted by looking at the realization of the budget and the output of goods and services produced by the government. Thus the possibility of potential state leakage can be observed when the output does not match the input. Another method to calculate the amount of state loss is by looking at the state revenue. The high potential state revenue may be reduced by corruption where some parties gain benefits from the revenue. Potential revenue can be measured based on the data that forms the components of state revenue. When the potential state revenue is considered to be significantly far off the realization, it can be used to seek the possibility of certain parties enjoy such benefits.

\section{2) The Role of Accountants in Achieving Good Public} Governance

The emergence of market mechanisms in the management of the state leads to the emergence new public governance concept where public involvement in state administration becomes quite dominant. The development of Public Private Partnership provides space for businessmen to be suppliers in the provision of public goods and services. On the one hand this gives a positive impact in the development of the construction. However, on the other hand this may lead to acts of corruption as a result of the desire of certain parties in winning the tender for the public procurement of goods and services. Based on data obtained from KPK's annual report, it is found that the greatest act of corruption comes from the public procurement of goods and services. Therefore accountants have an important role to improve the transparency and accountability of the state financial statements including the public procurement of goods and services. The participants of interview state that accountants may play an active role to ensure the transparency of the procurement of goods and services. Although the current procurement process has been conducted with the eprocurement system, it does not rule out the possibility of corruption by certain parties at the level of policy.

Corruption in Indonesia is already very alarming because it turns out that it has been committed since the planning phase. Such scenario of corruption involving politicians, bureaucrats and businessmen is already set up in the budgeting process. They have their own interests for the sake of mutual benefits. In fact in the case of disputed regional elections in Indonesia, those who involved in corruption is not limited to legislative, executive and businessmen but also the fourth party - the judiciary. Regarding political parties, accountants have a role in auditing their fundings and the financial statements of the parties or the candidates for regional leaderships. By auditing the fundings, the risk of corruption is expected to reduce because the validity of the source and management of the fundings may be trusted. The bribery committed by the businessmen may be reduced through the commitment of company accountants in conveying the true financial statement. Thus the company accountants may quickly identify the acts of bribery. Accountants with their role in reducing information asymmetry occurs among stakeholders of this state should be able to create a good climate of financial reporting from various aspects. Thus the transparency and accountability, the embodiment of good public governance is achieved.

\section{CONCLUSIONS, IMPLICATIONS AND LIMITATIONS OF THE STUDY}

\section{A. Conclusions}

Based on the identification of problems and the discussion in the previous chapter, the writer concludes:

- The results of this study shows that KPK collects the corruption evidences in various ways. To obtain sufficient preliminary evidence, KPK must have a minimum of two sufficient evidences to escalate the case from the inquiry process to the investigation process. KPK regularly studies the possibility of corruptions in the government institutions so that KPK may provide certain inputs to the relevant institutions for prevention efforts to do. After identifying the risks of corruption, KPK will evaluate the corruption case informed by the public. The identification of corruption is conducted by using a searching technique of perpetrator network and objects of corruption as well as using follow the money technique to calculate the losses of state.

- This study also shows that accountants play a role in reducing corruption starting from the prevention phase (development of anti-corruption culture), phase detect (calculate income countries), and the investigation carried out by the audit techniques. It means that if accountants play an active role in detecting corruption will reach good public governance.

\section{B. Implications of the Study}

This study contributes: Firstly to give recommendation to IAI, that IAI (Institute of Accountants Indonesia) is expected to provide ongoing training on forensic accounting and investigative audit. Secondly this study may encourage the government to optimize the role of accountant in reducing corruptions, does not the limit for the forensic accountant to detect the corruption, and to make regulations regarding the minimum competences and qualifications of investigators in order to tun an effective corruption detection technique in Indonesia.

\section{Limitations of the Study}

For further research it is necessary to do an interview to the perpetrators of corruption which can certainly provide more indepth information about the corrupt practices they do, their motives, their methods and the amount of state losses. With this information the detection of corruption can be conducted more accurately. Thus further research is recommended to add 
informants who are involved in corruption and are voluntarily willing to reveal the actual facts of corruption cases. The further researcher can investigate one type of corruption more specifically, such as extortion, bribery etc. in order to obtain a more detailed result.

\section{REFERENCES}

[1] National Strategy on the Prevention and Combating of Corruption Long Term (2012-2025) and the Medium Term (2012-2014)

[2] Neu et al (2012). Accounting and Network of Corruption. Accounting and Organization of Accounting Society

[3] Scahill (2007) Blackwater : The rise of the worlds most powerful mercenary army. Newyork Nation Book

[4] Neu et al (2012). Accounting and Network of Corruption. Accounting and Organization of Accounting Society

[5] Dye \& Stapenhurst (1998) Pillars of Integrity : The Importance of Supreme Audit Institustion in Curbing Corruption. Washington DC : The Economic Development Institute of The World Bank

[6] Neu et al (2012). Accounting and Network of Corruption. Accounting and Organization of Accounting Society

[7] Adam Graycar, Aiden Sidebottom, (2012) "Corruption and control: a corruption reduction approach", Journal of Financial Crime, Vol. 19 Iss: 4, pp.384- 399

[8] Pius (2011). Membangun Komitmen dan Gerakan Demokrasi Untuk Mencegah dan Memberantas Korupsi
[9] Ressy (2007) The Tradition of Corruption and the Challenge of Establishing a Clean Political Environment in Indonesia.

[10] Pius (2011). Membangun Komitmen dan Gerakan Demokrasi Untuk Mencegah dan Memberantas Korupsi

[11] Tuanakotta, Theodorus M. 2007. Akuntansi Forensik dan Audit Investigatif. Jakarta: Lembaga Penerbit Fakultas Ekonomi Universitas Indonesia.

[12] Albrecht, W. Steve and Chad O. Albrecht. 2003. Fraud Examination. Ohio: South-Western.

[13] Albrecht, W. Steve and Chad O. Albrecht. 2003. Fraud Examination. Ohio: South-Western.

[14] Everett,Neu \& Rahman (2007) Accounting and The Global Fight Againts Corruption. Accounting Organization and Society 32(6) 513-542

[15] Tuanakotta, Theodorus M. 2007. Akuntansi Forensik dan Audit Investigatif. Jakarta: Lembaga Penerbit Fakultas Ekonomi Universitas Indonesia.

[16] Sugiyono. 2010. Metode Penelitian Pendidikan (Pendekatan Kuantitatif, Kualitatif, dan R\&D). Bandung: Alfabeta.

[17] J. Clerk Maxwell, A Treatise on Electricity and Magnetism, 3rd ed., vol. Arens, Alvin et al. 2008. Auditing dan Jasa Assurance. Jakarta: Erlangga

[18] J. Clerk Maxwell, A Treatise on Electricity and Magnetism, 3rd ed., vol. Arens, Alvin et al. 2008. Auditing dan Jasa Assurance. Jakarta: Erlangga.

[19] Albrecht, W. Steve and Chad O. Albrecht. 2003. Fraud Examination. Ohio: South-Western.

[20] Law No. 20 Year 2001 Regarding Amandment Law No. 31 Year 1999 Regarding the Corruption Eradication 